\title{
Study of The Effect of Zeolite Catalyst Use on Renewable Energy Products from HDPE Plastic Pyrolysis
}

\author{
Nurull Fanani ${ }^{1}$, Eky Novianarenti $^{2}$, Erlinda Ningsih $^{3}$, Kartika Udyani $^{3}$, Agus Budianto ${ }^{3}$, \\ Abubakar Tuhuloula ${ }^{4}$ \\ ${ }^{1}$ Department of Electrical Engineering, University of Technology Surabaya \\ ${ }^{2}$ Department of Marine Engineering, Shipbuilding Institute of Polytechnic Surabaya \\ ${ }^{3}$ Department of Chemical Engineering, Institute of Technology Adhi Tama Surabaya \\ ${ }^{4}$ Department of Chemical Engineering, Lambung Mangkurat University Banjarbaru \\ Email: ${ }^{1}$ nf.fanni@gmail.com
}

\begin{abstract}
Nowadays, waste is a serious problem, especially plastic waste, which is quite alarming in the world. Plastic is waste that is difficult to degrade and takes hundreds of years to decompose. One of the promising technologies for recycling plastics is pyrolysis. This is the process of breaking long chains of polymers into hydrocarbons which are carried out at high temperatures. The purpose of this paper was to know the effect of using catalysts and non-catalysts on yield and calorific value. In this study, the pyrolysis process used a natural zeolite catalyst with a temperature of $500^{\circ} \mathrm{C} .50$ grams of HDPE Plastic feed was put into the reactor for 3 hours. The variations in the addition of Zeolite catalyst were $1.5,2.5,3.75$ and $5 \%$ wt. The results goals that the highest yield was $44.36 \%$ and the heating value of $10230.295 \mathrm{cal} / \mathrm{g}$ for the addition of 5 grams of catalyst. The addition of a catalyst can increase the conversion of plastic to fuel
\end{abstract}

Keywords: Catalyst, Plastic, HDPE, energy, pyrolysis

\section{1. Preliminary Study Overview}

Plastics are a type of macromolecule formed by the polymerization process, which is the combination of several simple molecules (monomers) through a chemical process into large molecules called polymers [1]. This plastic waste is difficult to break down by bacteria and microorganisms. Therefore, recycling is one step that can be done so that it is not environmentally friendly. As an illustration, plastic bag waste if dumped into the ground takes about 1000 years for this waste to be degraded and degraded by microorganisms [2].

Pyrolysis appears to be an awesome technique for converting plastic waste into more useful materials such as Natural Gas or Oil Fuel even into high-value feedstocks for the industry. Pyrolysis is a substantial technique in which polymers are converted into liquid oil, charcoal and gases at high temperatures though thermal decomposition [3-5]. Catalysts can be very beneficial in this process during the cracking of long polymer chains. Some product of the catalytic pyrolysis of plastic such as diesel and gasoline [6]. A range of catalysts have been utilized, including Red Mud [7], FCC [8], ZSM-5 [7], HZSM-5 [9], Y Zeolite [10], Fe2O3 [11], Al2O3, CA(OH)2 [12], and natural zeolite [13], in catalytic pyrolysis to improve the quality of liquid oil. Zeolites and mesoporous are the most frequently used catalysts materials because of their porous structure. A number of acid porous solids, such as amourphous materials is used in some study case of polyolefin catalytic cracking like HDPE. The used catalysts have high conversion effect over the plastic waste at lower temperature and decrease the activation energy [14]. Many researchers investigate the catalytic degradation of polymer wastes in last year ago. Catalyst more benefit by added in many sample to modify the products.

From this research, it encourages us to research the pyrolysis catalytic method of HDPE type plastic waste with natural zeolite catalysts to determine its effect on yield and calorific value so that this research is feasible. It is hoped that this research can reduce the abundant plastic waste. 


\section{Research Method}

Part of the second challange about this study used in analyzing the effects of pyrolysys are problem identification, variables is used and arrange of instrument, experimental setup, and analysis and discussion in depth about implemented of catalysts.

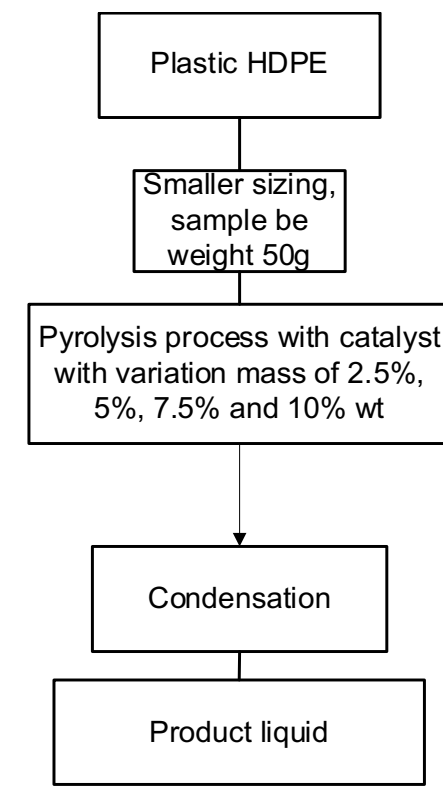

Figure 1. Flowchart of Experimental Oriented

\subsection{Experimental Setup}

At this section, facts are found that an interest process about the pyrolysis conditions of HDPEbased plastic waste, both in terms of yield and calorific value aspects related to reactor performance using Zeolite catalysts. From the findings on the HDPE plastic problem, we made a comparison between the yield and calorific value produced from HDPE which has been managed by the reactor and produces liquid. With the variants between the existing and ideal conditions, a problem formulation will be made based on the research.

\subsubsection{Variable identification}

The research variables are the variations used in the pyrolysis process: Fixed Variable (a) HDPE plastic mass (50g), (b) Nitrogen Pressure: $1 \mathrm{~kg} / \mathrm{cm} 3$; Independent variable addition of natural zeolite catalyst mass $(1.5 \%, 2.5 \%, 3.75 \%$ and $5 \% \mathrm{wt})$.

\subsubsection{Experimental Setup}

All of the catalytic degradation experiments of polyolefin mixed waste (RW) were applied in a stainless-steel semi-batch reactor with $500 \mathrm{~mL}$ volume equipped with a temperature measurement system. Some plastic from HDPE waste mixed with catalyst is fed into the reactor. The reaction system is shut down at $\mathrm{P}$ atm and then the heater is turned on. The pyrolysis was started from $18^{\circ} \mathrm{C}$ to a maximum of $550^{\circ} \mathrm{C}$ for about three hours.

The pyrolysis experiments were conducted base on dynamic process using a heating rate of $10^{\circ} \mathrm{C}$ / min and a different time set by the temperature program. Temperature handled using a PID temperature controller (Unitronics V570). The vaporized product from the reactor is accumulate through a stainless pipe in that it reaches the base of the reactor then is released into the condenser system to condense the condensation of the product. The condensing vapor from the reactor is cooling down by the condenser were connected to the reactor. The dynamics of the pyrolysis process are controlled by time measuring the volume of oil collected. The liquid product received is accumulated into a condenser and then 
disscussed. Most of the condensable product is accumulate in the first condenser. Based on the operating conditions, sometimes condensate is observed in the second condenser. The viscous liquid product appears above $410^{\circ} \mathrm{C}$.

Tabel 1. Pyrolysis reactor spesifications

\begin{tabular}{lc}
\hline \multicolumn{1}{c}{ Parameter } & Value \\
\hline Heating tank (height) & $370 \mathrm{~mm}$ \\
Heating tank (diameter) & $300 \mathrm{~mm}$ \\
Catalytic chamber (height) & $250 \mathrm{~mm}$ \\
Catalytic chamber (diameter) & $175 \mathrm{~mm}$ \\
Reactor (total capacity) & $25 \mathrm{~L}$ \\
Catalytic chamber (total capacity) & $1.5 \mathrm{~L}$ \\
Condenser (length) & $870 \mathrm{~mm}$ \\
Condenser (diameter) & $145 \mathrm{~mm}$ \\
Temperature (maximum) & $500^{\circ} \mathrm{C}$ \\
\hline
\end{tabular}

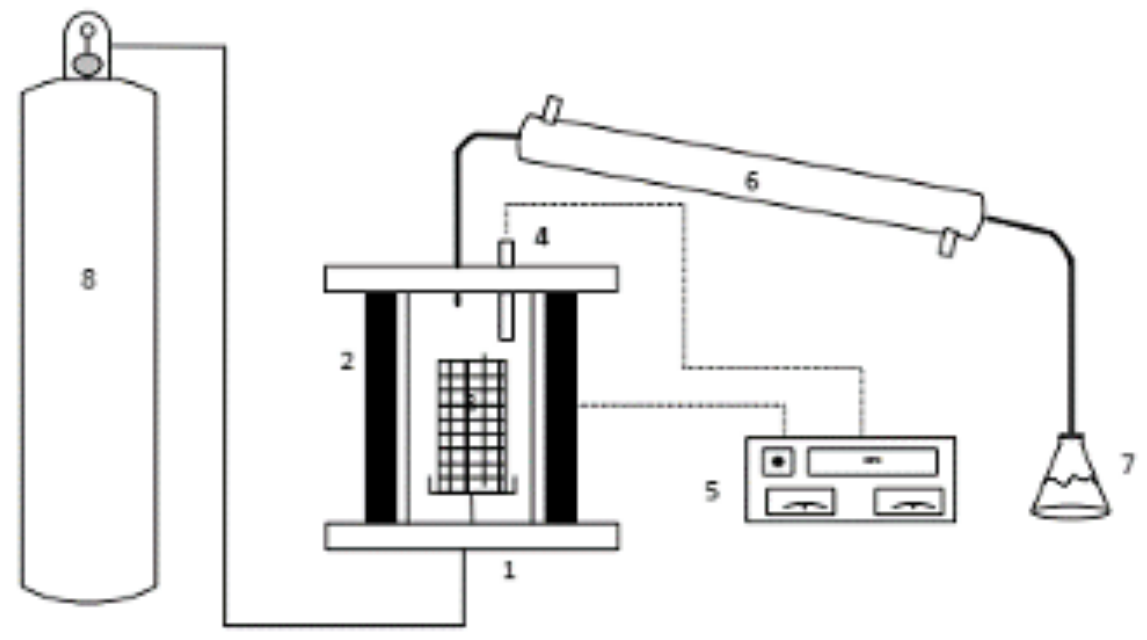

Figure 2. Flowchart of Experimental Oriented

Image name (1) Reactor pyrolysis, (2) Electrival heater, (3) Sample placed, (4) Thermocouple, (5) Controlling instrument, (6) Condensor, (7) Liquid placed, (8) Nitrogen tube

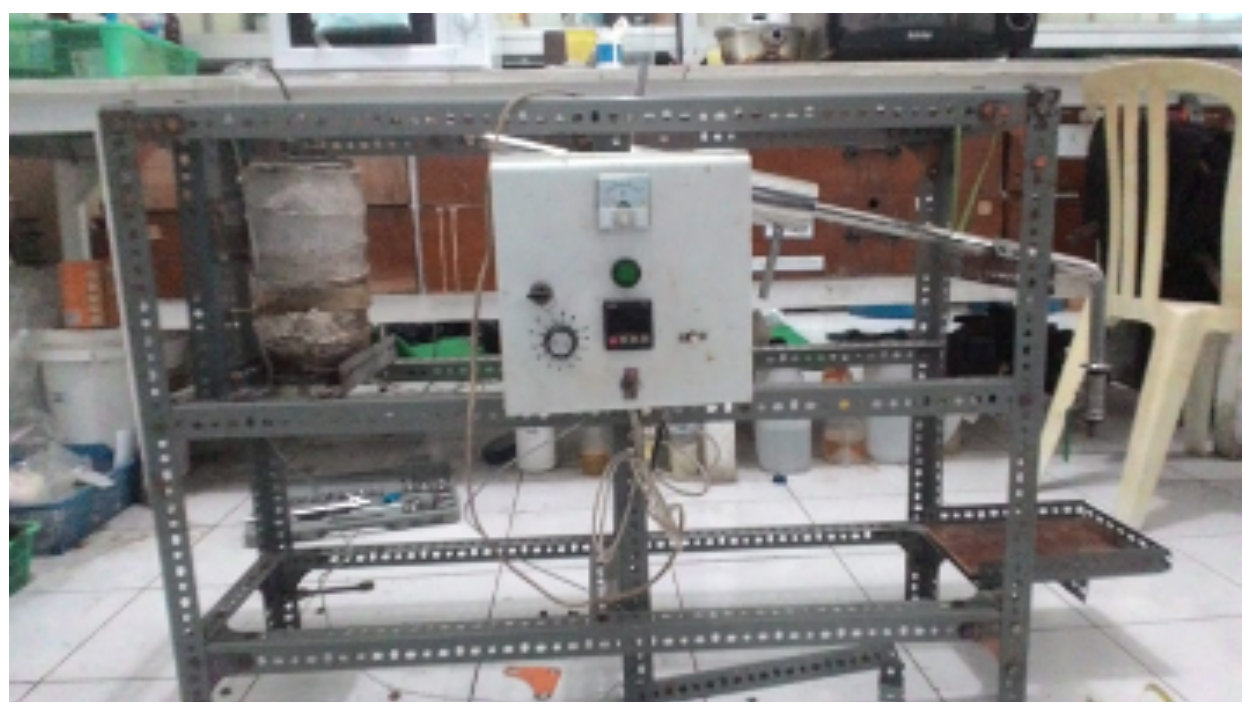

Figure 3. Flowchart of Experimental Oriented 


\section{Result and Discussion}

Pyrolysis of High-Density Polyethylene (HDPE) plastic is conducted in a semi-batch reactor made of stainless steel at a certain temperature using a counter flow condenser cooler. Pyrolysis was carried out with a residence time of 3 hours. The raw material used is a plastic bottle cap, after heating in the reactor at a certain temperature (according to variables) it will be decomposed into a gas which can condense into a liquid. The pyrolysis process starts at a temperature of $500-650^{\circ} \mathrm{C}$ suppose to know the effect of temperature on the liquid yield, heating value and the fraction formed.

The effect of adding a catalyst on the liquid yield of pyrolysis products

Figure 4 shows that the liquid yield from pyrolysis increases with the increase in the amount of catalyst that is inserted. The highest yield value of HDPE plastic was obtained at $44.3 \%$ with the addition of 5 grams of catalyst.

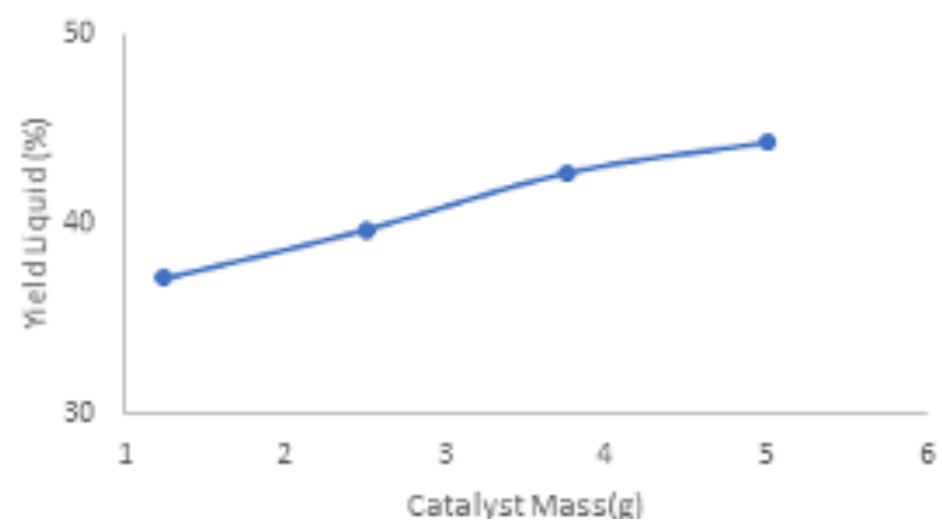

Figure 4. Influences addition of catalysts vs yield liquid products pyrolysis product HDPE

Reformed catalysts show a double effect. Whilst acidic sites accelerate the isomerization reaction, metallic sites accelerate the hydrogenation and dehydrogenation reaction [18]. Futhermore, the technique of these reformed catalysts will improve the overall catalytic pyrolysis efficiency and increase the product quality. However, some research and trouble shooting for improvement still remain in the catalytic pyrolysis of plastic waste.

The effect of adding a catalyst on the liquid calorific value of pyrolysis products

From figure 5, the results of the liquid calorific value of pyrolysis products are obtained in several variations of the addition of catalysts and the highest value for HDPE plastic is $10230.295 \mathrm{cal} /$ $\mathrm{g}$. The calorific value of HDPE plastic is $10136.11 \mathrm{cal} / \mathrm{g}$ which is close to the kerosine calorific value of about $10270 \mathrm{cal} / \mathrm{g}$ [16]. The results of the heating value show a deflation in line with the increasing in pyrolysis temperature. This is due to the amount of water content in the product liquid which is formed from oxygen that enters from the leakage of the pyrolysis reactor so that the calorific value of the liquid product decreases.

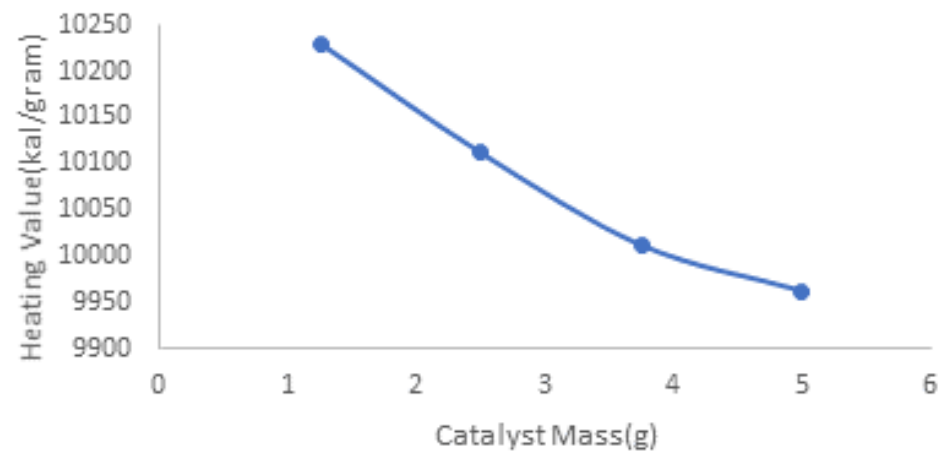

Figure 5. Influences addition of catalysts vs heating value liquid products pyrolysis 
The more water content, the more energy is needed to evaporate the water and the lower the heat generated from the combustion [17]. Figure 5 shows that the calorific value of the liquid from pyrolysis decreases with the addition of more catalysts. This is because there is still water content in the product liquid so that the water can affect the resulting calorific value.

\section{Conclusion}

Based on the experimental discussion in section four, it is true that the waste plastic is able to get the high yield $44.36 \%$ of liquid product by using reactor. The employed Zeolite as a catalyst successfully converts waste plastic into liquid fuel. Higher yield or liquid products was reach for the temperature above $500^{\circ} \mathrm{C} .50$ grams of HDPE Plastic feed was put into the reactor for 3 hours. The variations in the addition of Zeolite catalyst were 1.5, 2.5, 3.75 and 5\%wt. The results showed that the highest yield was $44.36 \%$ and the heating value of $10230.295 \mathrm{Cal} / \mathrm{g}$ for the addition of 5 grams of catalyst. The addition of a catalyst can increase the conversion of plastic to fuel.

\section{Reference}

[1] Surono, U. B., Ismanto. 2016. Pengolahan Sampah Plastik Jenis PP, PET dan PE Menjadi Bahan Bakar Minyak dan Karakteristiknya. Journal Mekanika dan Sistem Termal 1 (1) pp. 32-37

[2] Bashir, N. H. H. 2013. Plastic Problem in Africa. Japanese Journal of Veterinary Research, 61, pp. 1-11

[3] Chen D, Yin L, Wang H, He P. 2014. Pyrolysis Technologies For Municipal Solid Waste: A Review. Journal of Waste Management. 34: 2466-2486.

[4] Ouda O K M, Raza S A, Nizami A S, Rehan M, Al-Waked R, Korres N E. 2016. Waste to Energy Potential: A Case Study of Saudi Arabia. Renewable and Sustainable Energy Reviews. 61: 328340.

[5] Anjum M, Miandad R, Waqas M, Ahmad I, Alafif Z O A, Aburiazaiza A S, Barakat M A, Akhtar T. 2016. Solid Waste Management In Saudi Arabia: A Review. J. Appl. Agric. Biotechnol., 1(1): $13-26$

[6] A. Marcilla, F. Go'mez - Siurana, J. Valde's. 2008. Influence of the temperature on the composition of the coke obtained in the catalytic cracking of low density polyethylene in the presence of USY and HZSM-5 zeolites, Microporous and Mesoporous Materials, 109, 420-428.

[7] Lopez A, Marco I D, Caballero B M, Laresgoiti M F, Adrados A, Aranzabal A. 2011. Catalytic Pyrolysis of Plastic Waste with Two Different Types of Catalytic: ZSM - Zeolite and Red Mud. Applied Catalysts B: Environmental 104. 211-219c.

[8] Lee K H. 2009. Thermal and Catalytic Degradation of Pyrolytic Oil from Pyrolysisi of Municipal Plastic Waste. Journal of Analytical and Applied Pyrolysis 85372 - 379.

[9] Hernandez M D R, Gomez A, Garcia A N, Agullo J, Marcilla A. 2007. Effect of the Temperature in The Nature and Extension of The Primary and Secondary Reactions in The Thermal and HZSM-5 Catalytic Pyrolysis of HDPE. Applied Catalysts A: General 317: 183-194.

[10] Lee K H. 2012. Effects of the Ttpes of Zeolite on Catalytic Upgrading of Pyrolysis Wax Oil. Journal of Analytical and Applied Pyrolysis $94209-214$.

[11] Sarker M and Rashid M M. 2013. Waste Plastics Mixture of Polystyrene and Polypropylene into Light Grade Fuel using Fe2O3 Catalyst. International Journal of Renewable Energy. Technology Research (IJRETR) Vol. 2, No. 1, PP: 17 - 28.

[12] Sarker M, Kabir A, Rashid MM, Molla M, Mohammad A S M D. 2011. Waste Polyethylene Terephthalate (PETE-1) Conversion into Liquid Fuel. Journal of Fundamentals of Renewable Energy and Applications Vol.1: 5 pages.

[13] Syamsiro M, Saptoadi H, Norsujianto T, Noviasri, Cheng S, Alimuddin Z, Yoshikawa K. 2014. Fuel oil production from Municipal plastic wastes in sequential pyrolysis and catalytic reforming reactors. Energy Procedia 47. 180-188.

[14] M. N. Almustapha, M. John Andrésen. 2012. Recovery of valuable chemicals from high density polyethylene (HDPE) polymer: a catalytic approach for plastic waste recycling, International Journal of Environmental Science and Development, 3(3), 263-267 
[15] Sogancioglu, M, Esra, Y, Gulnare, A. 2017. Pyrolysis of waste high density polyethylene (HDPE) and low density polyethylene (LDPE) plastics and production of epoxy composites with their pyrolysis chars. Journal of Cleaner Production. Selcuk University, Faculty of Engineering, Dept. of Chemical Engineering, Turkey.

[16] Mulyadi, E., 2010, “ Kinetika Reaksi Katalitik Dekomposisi Gambut”, Semnas Hasil Penelitian Balitbang prov Jatim, ISBN 978-979-10-8.

[17] Ratnasari D.K, Nahil, M.A, William Paul T, 2017. Catalytic oyrolisis of waste plastics using staged catalysis for production of gasoline range hydrocarbon oils. Journal of analytical and applied pyrolysis 124 (631-637). University of leeds. UK

[18] Panda A K, Singh R K, Mishra D K 2010. Thermolysis of waste plastics to liquid fuel. A suitable 5 method for plastic waste management and manufacture of value added products-A world 6 prospective. Renewable and Sustainable Energy Reviews. 14: 233-248 